\title{
Analisis Kualitas Laba Perbankan Syariah di Indonesia
}

\section{Earning Quality Analysis of Sharia Bank in Indonesia}

\author{
Riko Adimulya ${ }^{1}$, Hartoyo $^{2}$, Imam Teguh Saptono $^{3}$ \\ ${ }^{1}$ Sekolah Pascasarjana, Institut Pertanian Bogor, Jalan Raya Dramaga, Bogor 16680, Indonesia, \\ riko.adimulya@gmail.com \\ ${ }^{2}$ Sekolah Pascasarjana, Institut Pertanian Bogor, Jalan Raya Dramaga, Bogor 16680, Indonesia, \\ hrtipb@gmail.com \\ ${ }^{3}$ Sekolah Pascasarjana, Institut Pertanian Bogor, Jalan Raya Dramaga, Bogor 16680, Indonesia, \\ itsaptono@yahoo.com
}

\begin{abstract}
The firms tend to perform earning management, mainly due to there was an agency problem amongst the management (agent) and the owner (principal), in more specifically because the lack of corporate governance, manager's bonus plan, decreasing of supervision, debt-covenant, and economicmeltdown condition. The earning management practice is potentially done by any firms included the sharia bank. The earning management practice will affect the firm's earnings quality as represented in the financial report. Despite the accounting treatment of mudharabah-musyarakah financing uses cashbasis, the sharia bank may manipulate the earnings when they determine the profit from the investments which will be shared to both the bank and investor. The study aims to investigate the differences of earnings quality and examine the effect of mudharabah-musyarakah financing and leverage to earnings quality, within Bank Umum Syariah (BUS) and Unit Usaha Syariah (UUS) during economic meltdown period in Indonesia between 2014-2016. The results show that there are no significant differences in the earnings quality within sharia bank types during the observed period. Furthermore, the results show that the effect of mudharabah-musyarakah financing and leverage to earnings quality within sharia bank types are in significant within the same observed period.
\end{abstract}

Keywords: Earning management, earnings quality, leverage, mudharabah-musyarakah financing, sharia bank

\begin{abstract}
Abstrak. Penyebab perusahaan melakukan praktik manajemen laba yang paling utama adalah adanya masalah keagenan antara pengelola (agent) dan pemilik (principal) dari perusahaan. Alasan yang lebih spesifik karena kelemahan tata kelola perusahaan, paket bonus/kompensasi pengelola, turunnya peran pengawas, persyaratan utang, dan kondisi perekonomian yang melemah. Praktik manajemen laba berpotensi dijalankan oleh berbagai perusahaan termasuk bank syariah. Praktik manajemen laba akan berpengaruh terhadap kualitas laba yang tercermin dalam laporan keuangan. Meskipun perlakuan akuntansi pembiayaan mudharabah-musyarakah menggunakan basis kas, namun masih memungkinkan bagi bank syariah untuk memanipulasi labanya yakni pada saat penentuan laba untuk dibagihasilkan antara bank dan investor. Penelitian ini ditujukan untuk mengidentifikasi perbedaan kualitas laba, menganalisis pengaruh pembiayaan mudharabah-musyarakah dan utang terhadap kualitas laba di Bank Umum Syariah (BUS) dengan Unit Usaha Syariah (UUS) pada periode terjadi pelemahan perekonomian Indonesia di tahun 2014-2016. Hasil penelitian menunjukkan bahwa tidak ada perbedaan yang signifikan kualitas laba di Bank Umum Syairah (BUS) dan Unit Usaha Syariah (UUS) pada periode waktu pengamatan. Selanjutnya, pembiayaan mudharabah-musyarakah dan utang tidak berpengaruh secara signifikan terhadap kualitas laba baik di Bank Umum Syariah (BUS) dan Unit Usaha Syariah (UUS) pada periode pengamatan yang sama.
\end{abstract}

Kata kunci: Bank syariah, kualitas laba, manajemen laba, pembiayaan mudharabah-musyarakah, utang.

\section{PENDAHULUAN}

Manipulasi laporan keuangan terbesar yang pernah terjadi yaitu di tahun 2002, melibatkan perusahaan besar yang terdaftar di New York Stock Exchange, seperti Enron, WorldCom, dan Tyco yang terdaftar di bursa efek New York, serta akuntan publik Arthur Anderson (Wan Abdullah, 2013). Isu terkait dengan penyajian laporan keuangan juga terjadi di Indonesia, melibatkan satu institusi bank yang 
terdaftar di Bursa Efek Indonesia (BBKP), yang menyajikan laba perusahaan lebih besar dari nilai sebenarnya di tahun 2016 (Banjarnahor, 2018). Dua tahun berselang, di tahun 2018, perusahaan penerbangan nasional yang juga terdaftar di Bursa Efek Indonesia (GIAA), melakukan revisi atas nilai pendapatan yang dilaporkan tidak sesuai dengan nilai sebenarnya di tahun 2017 (Fauzia, 2019).

Manipulasi laba pada laporan keuangan sangat terkait dengan praktik manajemen laba (earnings management), di mana perusahaan melakukan rekayasa terhadap laba yang disajikan pada laporan keuangannya untuk tujuan dan alasan tertentu dan pencatatan tersebut dijalankan tanpa transaksi riil yang mendasarinya (Chen et al., 2010). Praktik manajemen laba muncul karena agency problem, di mana terdapat perbedaan kepentingan antara pengelola (agent) dengan pemilik (principal) perusahaan (Jensen dan Meckling, 1976), bonus plan, debt covenant, political cost (Watt dan Zimmerman, 1986), lemahnya tata kelola perusahaan, paket kompensasi manajer, penurunan kualitas audit, kelemahan pengawasan oleh para analis keuangan, dan karena kondisi perekonomian yang melemah/krisis (Dechow dan Dichev, 2002). Praktik manajemen laba yang dijalankan oleh pengelola perusahaan berdampak terhadap kualitas laba perusahaan yang tersaji di dalam laporan keuangan.

Dechow dan Dichev (2002) menjelaskan bahwa pada dasarnya laba perusahaan yang tersaji di dalam laporan keuangan terbentuk dari dua komponen yaitu nilai arus kas dan akrual. Oleh karena dalam proses akrual terdapat perbedaan waktu antara pencatatan pendapatan/biaya secara akuntansi dengan penerimaan/pembayaran tunai atas pendapatan/biaya tersebut, maka perusahaan berpotensi memanfaatkan celah tersebut untuk melakukan rekayasa laba.

Model akrual yang dibangun oleh Dechow dan Dichev (2002) merupakan salah satu model yang dapat digunakan untuk mengetahui kualitas laba perusahaan dengan menggunakan informasi keuangan yang tersaji pada laporan keuangan. Ukuran kualitas laba adalah kualitas akrual, yang ditunjukkan dengan nilai standar deviasi residual dari hasil regresi model tersebut, di mana kualitas laba dinilai lebih baik apabila nilai standar deviasi residualnya lebih kecil.

Makke (2016) membagi bank syariah berdasarkan tingkat kepatuhannya, dengan urutan sebagai berikut: Pertama, stand-alone sharia bank yang beroperasi di negara yang telah secara penuh menjalankan prinsip keuangan syariah, selanjutnya independent sharia bank, institusi yang dimiliki bank konvensional dan beroperasi secara mandiri, kemudian yang terakhir adalah sharia business windows, unit bisnis yang merupakan bagian di dalam bank konvensional. Sedangkan kategori bank syariah menurut ketentuan Bank Indonesia terdiri dari Bank Umum Syariah (BUS) termasuk di dalamnya Unit Usaha Syariah (UUS) dan Bank Pembiayaan Rakyat Syariah (BPRS).

Dalam standar akuntansi syariah dijelaskan bahwa untuk mencapai tujuannya, maka laporan keuangan disusun atas dasar akrual, di mana pengaruh transaksi dan peristiwa lain diakui pada saat kejadian, dan bukan pada saat kas atau setara kas diterima atau dibayar (IAI, 2017). Berbeda dengan bank konvensional yang sepenuhnya menggunakan dasar akrual, pencatatan transaksi di bank syariah mengkombinasikan dasar kas dan akrual yang diselaraskan dengan akad transaksi yang mendasarinya (BI, 2013).

Untuk akad jual-beli (murabahah), jual beli dengan sistem pesanan (istishna, salam), sewa (ijarah) dengan prinsip angsuran, pengakuan dan pencatatan pendapatan/biaya menggunakan dasar akrual. Sedangkan pengakuan dan pencatatan pendapatan/biaya dengan akad kerja sama investasi bagi hasil (mudharabah dan musyarakah) menggunakan dasar kas (BI, 2013). Meskipun menggunakan dasar kas, skema investasi bagi hasil (mudharabah dan musyarakah) berpotensi menimbulkan masalah saat bank syariah menentukan laba untuk bagi hasil dari investasi tersebut, sehingga patut diduga dalam proses ini bank syariah dapat melakukan manipulasi laba (Al Shattarat dan Atmeh, 2016).

Di samping memperoleh dana dari pihak ketiga (DPK) seperti tabungan dan deposito, bank syariah juga menerima pendanaan berupa utang (leverage) antara lain dari penerbitan surat berharga atau pinjaman yang diterima. Persyaratan (debt covenant) yang disertakan di dalam perjanjian utang 
biasanya diatur oleh kreditur dan wajib dipenuhi oleh pihak bank sebagai pihak yang berutang. Menurut Valipour dan Moradbeygi (2011) perusahaan yang memiliki utang yang lebih besar cenderung melakukan praktik manajemen laba untuk menghindari pelanggaran terhadap debtcovenant yang telah disepakati di dalam perjanjian kredit.

Indikator perekonomian Indonesia secara makro dari tahun 2011 sampai dengan tahun 2017 menunjukkan bahwa pelemahan perekonomian nasional terjadi pada periode tahun 2014-2016. Hal ini tercermin dari tingkat pertumbuhan ekonomi (PDB) Indonesia menurun dari 6.2\% di tahun 2011 menjadi titik terendah sebesar 4.8\% di tahun 2015 (BPS, 2019), melemahnya nilai tukar mata uang rupiah terhadap US dollar dari Rp 8,773/USD di tahun 2011 menjadi Rp 13,389/USD di tahun 2015, dan naiknya tingkat suku bunga acuan untuk mata uang rupiah, dari 6\% p.a. di tahun 2011 menjadi $7.5 \%$ p.a. di tahun 2015 (BI, 2019). Pada kondisi terjadi pelemahan perekonomian ini, dengan tujuan menjaga kredibilitas di mata investor/kreditur dan pihak terkait lainnya, perusahaan berpotensi melakukan praktik manajemen laba untuk mempertahankan kualitas laba pada level yang dierima oleh para pemangku kepentingan (Dechow dan Dichev 2002).

Penelitian ini ditujukan untuk mengidentifikasi perbedaan kualitas laba dan menganalisis pengaruh pembiayaan investasi bagi hasil (mudharabah dan musyarakah) dan utang (leverage) terhadap kualitas laba di Bank Umum Syariah (BUS) dan Unit Usaha Syariah (UUS) pada periode pelemahan perekonomian Indonesia periode tahun 2014-2016.

\section{TINJAUAN PUSTAKA}

\section{Masalah Keagenan (Agency Problem)}

Teori mengenai perusahaan (Jensen dan Meckling, 1976) menjelaskan bahwa terdapat hubungan antara perilaku manajerial, biaya keagenan dan struktur kepemilikan, di mana struktur kepemilikan perusahaan akan memengaruhi perilaku manajerial yang berpotensi memunculkan biaya keagenan. Masalah keagenan (agency problem) ini muncul sebagai akibat dari ketidakseimbangan porsi kepemilikan perusahaan di antara pengelola (agent) dengan pemilik (principal), di mana kepemilikan perusahaan umumnya dominan dikuasai oleh pemilik.

Masalah keagenan ini juga menciptakan konflik kepentingan dari pengelola yang berpotensi melanggar kontrak kerja yang disepakati dengan mengambil kebijakan dan tindakan yang ditujukan untuk kepentingan pribadi, di antaranya melalui praktik manajemen laba. Dampak lain masalah keagenan ini adalah timbul biaya keagenan yang harus ditanggung oleh pemilik. Hal tersebut berpotensi mengurangi marjin keuntungan yang akan diperoleh antara lain pengeluaran untuk kompensasi bagi pengelola (bonus) dan biaya untuk pengawasan (auditor).

\section{Akuntansi Perbankan Syariah}

Pengakuan dan pencatatan pendapatan/biaya atas transaksi di bank syariah diselaraskan dengan akad transaksi yang mendasarinya. Merujuk kepada standar akuntansi keuangan syariah (IAI, 2017), untuk akad transaksi jual beli (murabahah, istisna, salam) yang dibayarkan sekaligus secara tunai dan akad kerjasama investasi bagi hasil seperti mudharabah dan musyarakah, pengakuan dan pencatatan atas pendapatan/biayanya menggunakan dasar kas. Sedangkan untuk transaksi dengan akad jual beli (murabahah, istisna, salam) dengan skema pembayaran angsuran dan akad sewa menyewa (ijarah), maka pendapatan/biaya dicatat sementara pada pos neraca di sisi piutang dan utang berupa pendapatan/biaya yang ditangguhkan.

Selanjutnya secara berkala, pengakuan dan pencatatan atas pendapatan/biaya di laporan laba rugi dijalankan dengan menggunakan dasar akrual. Tata cara penetapan besaran pendapatan/biaya yang akan diamortisasi/akrual secara periodik tersebut, dihitung dengan menggunakan pilihan metode yang telah diatur oleh regulator perbankan syariah. Hal tersebut dilakukan sebagaimana yang tertuang di dalam Pedoman Akuntansi Perbankan Syariah Indonesia (BI, 2013). 
Menurut Dechow dan Dichev (2002), secara prinsip laba perusahaan terbentuk dari dua komponen yakni nilai arus kas operasional dan akrual. Hal tersebut menyebabkan perusahaan berpotensi melakukan praktik manajemen laba melalui rekayasa nilai akrual, antara lain dengan melakukan pengakuan dan pencatatan ke pos pendapatan lebih awal dengan porsi nominal lebih besar, serta menunda pengakuan dan pencatatan ke pos biaya. Atau perusahaan dapat melakukan hal sebaliknya, tergantung dari tujuan yang hendak dicapai. Praktik manajemen laba yang dijalankan oleh perusahaan berdampak terhadap kualitas laba sebagaimana tersaji di dalam laporan keuangan perusahaan.

\section{Model Pengukuran Kualitas Laba}

Model akrual banyak digunakan dalam penelitian untuk mengukur kualitas laba (praktik manajemen laba) di perusahaan, di mana proksi untuk kualitas laba adalah kualitas akrual. Model akrual ini ditujukan untuk mengestimasi non-discretionary accrual (NDA), maupun discretionary accrual (DA). Merujuk kepada Dechow et al. (2010), model tersebut antara lain adalah sebagai berikut:

\begin{tabular}{|c|c|c|}
\hline Model & Persamaan & Keterangan \\
\hline $\begin{array}{l}\text { The Healy Model } \\
\text { (1985) }\end{array}$ & $\mathrm{NDA}_{\mathrm{t}}=1 / \mathrm{n} \Sigma \tau\left(\mathrm{TA} \tau / \mathrm{A} \tau_{-1}\right)$ & $\begin{array}{l}\text { NDA periode } \mathrm{t} \text { dipengaruhi oleh rata-rata dari } \\
\text { akumulasi total akrual periode } \mathrm{t} \text { terhadap total aset } \\
\text { periode } \mathrm{t}-1 \text {. }\end{array}$ \\
\hline $\begin{array}{l}\text { The DeAngelo } \\
\text { Model (1986) }\end{array}$ & $\begin{array}{l}\mathrm{NDA}_{\mathrm{t}}=\mathrm{TA}_{\mathrm{t}-1} / \mathrm{A}_{\mathrm{t}-2} \\
\mathrm{DA}_{\mathrm{t}}=\left(\mathrm{TA}_{\mathrm{t}} / \mathrm{A}_{\mathrm{t}-1}\right)-\mathrm{NDA}_{\mathrm{t}}\end{array}$ & $\begin{array}{l}\text { NDA periode } t \text { dipengaruhi oleh persentase total akrual } \\
\text { periode } t-1 \text { terhadap total aset periode } t-2 \text {. Sedangkan } \\
\text { DA merupakan selisih antara persentase total akrual } \\
\text { periode } t \text { terhadap total aset periode } t-1 \text { dengan NDA } \\
\text { periode } t \text {. }\end{array}$ \\
\hline Jones model (1991) & $\mathrm{ACC}_{\mathrm{t}}=\alpha+\beta_{1} \Delta \mathrm{REV}_{\mathrm{t}}+\beta_{2} \mathrm{PPE}_{\mathrm{t}}+\varepsilon_{\mathrm{t}}$ & $\begin{array}{l}\text { Akrual pada periode } \mathrm{t} \text { dipengaruhi oleh perubahan } \\
\text { penjualan dan nilai aset tetap pada periode } \mathrm{t} \text {. Sedangkan } \\
\text { nilai residual adalah korelasi akrual, laba dan arus kas. }\end{array}$ \\
\hline $\begin{array}{l}\text { Modified Jones } \\
\text { model (Dechow } \\
\text { et.al., 2010) }\end{array}$ & $\mathrm{ACC}_{\mathrm{t}}=\alpha+\beta_{1}\left(\Delta \mathrm{REV}_{\mathrm{t}}-\Delta \mathrm{REC}_{\mathrm{t}}\right)+\beta_{2} \mathrm{PPE}+\varepsilon_{\mathrm{t}}$ & $\begin{array}{l}\text { Akrual pada periode t dipengaruhi oleh selisih } \\
\text { perubahan penjualan dengan perubahan penjualan } \\
\text { secara kredit dan nilai aset tetap pada periode t. Nilai } \\
\text { penjualan secara kredit dikeluarkan dari persamaan } \\
\text { karena seringkali menjadi media untuk manipulasi laba. } \\
\text { Nilai residual adalah korelasi akrual, laba dan arus kas. }\end{array}$ \\
\hline $\begin{array}{l}\text { Performance } \\
\text { matched (Kothari et } \\
\text { al., 2005) }\end{array}$ & $\mathrm{ACC}_{\mathrm{t}}=\alpha+\beta_{1} \Delta \mathrm{REV}_{\mathrm{t}}+\beta_{2} \mathrm{PPE}_{\mathrm{t}}+\beta_{2} \mathrm{ROA}_{\mathrm{t}}+\varepsilon_{\mathrm{t}}$ & $\begin{array}{l}\text { Akrual pada periode } \mathrm{t} \text { dipengaruhi oleh perubahan } \\
\text { penjualan, nilai aset tetap dan rasio laba terhadap aset } \\
\text { pada periode t. Nilai residual adalah korelasi akrual, } \\
\text { laba dan arus kas. }\end{array}$ \\
\hline $\begin{array}{l}\text { Dechow and } \\
\text { Dichev approach } \\
\text { (2002) }\end{array}$ & $\Delta \mathrm{WC}_{\mathrm{t}}=\alpha+\beta_{1} \mathrm{CFO}_{\mathrm{t}-1}+\beta_{2} \mathrm{CFO}_{\mathrm{t}}+\beta_{3} \mathrm{CFO}_{\mathrm{t}+1}+\varepsilon_{\mathrm{t}}$ & $\begin{array}{l}\text { Perubahan modal kerja pada periode } t \text { dipengaruhi oleh } \\
\text { arus kas operasional pada periode } t-1 \text {, arus kas } \\
\text { operasional periode } t \text { dan arus kas operasional periode } \\
\mathrm{t}+1 \text {. Standar deviasi dari residual menunjukan kualitas } \\
\text { akrual, semakin kecil nilainya maka kualitas akrual } \\
\text { semakin baik. }\end{array}$ \\
\hline
\end{tabular}

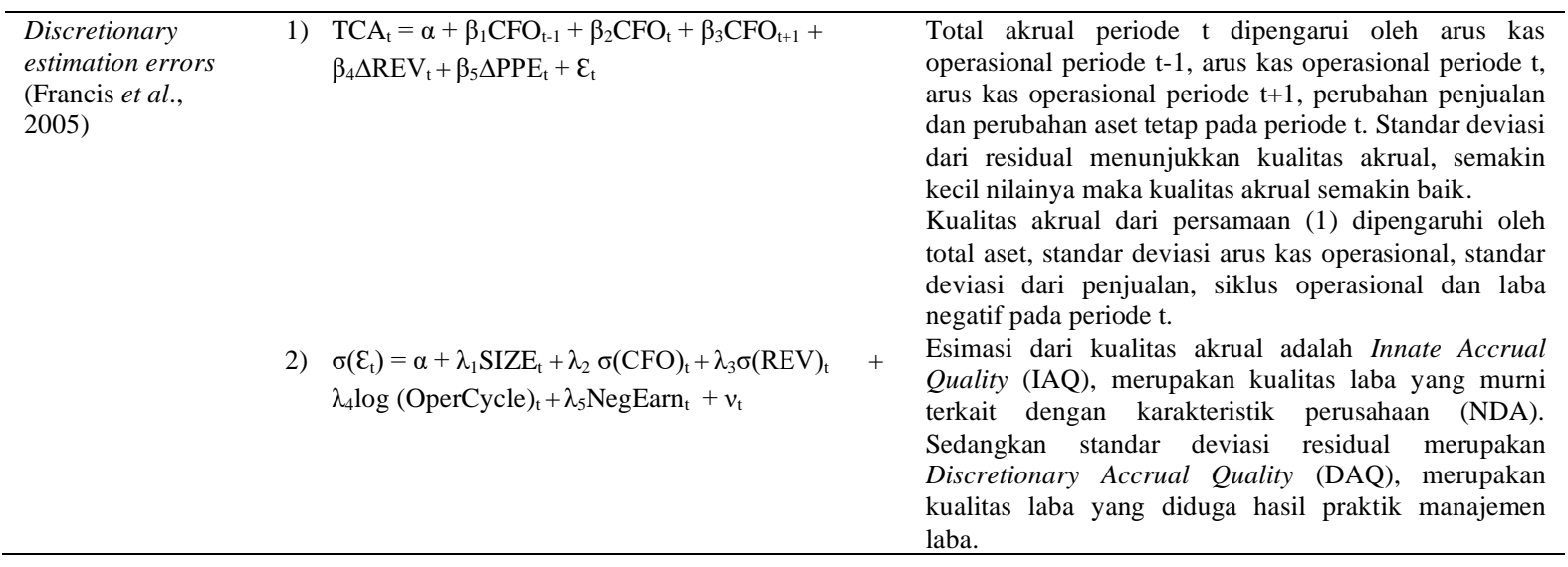




\section{Kajian Penelitian Terdahulu}

Penelitian terkait dengan praktik manajemen laba telah banyak dilakukan, terutama untuk sampel perusahaan-perusahaan konvensional. Sedangkan untuk sampel perusahaan berbasis syariah belum banyak penelitiannya. Johl et al. (2003) meneliti praktik manajemen laba pada perusahaan yang terdaftar di bursa Kuala Lumpur Malaysia, untuk periode sebelum dan setelah krisis keuangan di Asia Timur pada tahun 1997, dengan temuan bahwa sebelum periode krisis, tidak ditemukan perbedaan adanya praktik manajemen laba untuk perusahaan yang diperiksa oleh Auditor Big-5 dan Non-Big-5. Namun setelah periode krisis ditemukan perbedaannya, di mana perusahaan yang diperiksa oleh Auditor Big-5 memiliki kualitas laba yang lebih tinggi. Selanjutnya, Berndt dan Offenhammer (2010) meneliti praktik manajemen laba oleh bank publik di Austria, Jerman dan Swiss pada periode sebelum krisis keuangan global tahun 2006-2008, dan ditemukan terjadi peningkatan praktik manajemen laba selama periode krisis tersebut.

Selanjutnya, Ghosh dan Moon (2010) meneliti hubungan antara besaran utang dengan kualitas laba, dengan mengunakan data perusahaan dari Compustat di tahun 2006. Hasil penelitian tersebut menyimpulkan bahwa turun naiknya kualitas laba sejalan dengan besarnya utang, di mana dalam hal ini, pengelola perusahaan memilih untuk melakukan praktik manajemen laba daripada melanggar debt covenant yang berbiaya tinggi. Sejalan dengan penelitian sebelumnya, Valipour dan Moradbeygi (2011) meneliti hubungan antara utang dengan kualitas laba pada perusahaan yang terdaftar di Teheran Stock Exchange tahun 2005 - 2009, dan menyimpulkan bahwa utang adalah salah satu penyebab kualitas laba menjadi rendah, dan perusahaan yang kecil utangnya tidak melakukan manipulasi laba karena tidak memiliki risiko untuk melanggar debt covenant.

Kemudian Makke (2016) meneliti kualitas laba di setiap tipe bank syariah, hubungannya dengan leverage dan country effect saat periode krisis global di tahun 2008. Hasil penelitian tersebut menunjukkan bahwa tidak ada perbedaan signifikan kualitas laba di masing-masing tipe bank syariah, utang dan country effect tidak berdampak kepada kualitas laba. Selanjutnya, Hamdi dan Zarai (2012) meneliti praktik manajemen laba di bank syariah dengan objek penelitian sejumlah bank syariah di 27 negara antara tahun 2000-2009. Hasil penelitian tersebut menyimpulkan bahwa bank syariah tidak melakukan praktik manajemen laba.

Dari kajian penelitian di atas, dapat dicatat bahwa perusahaan berpotensi melakukan praktik manajemen laba pada kondisi pelemahan perekonomian (krisis). Besarnya utang (leverage) umumnya berpengaruh terhadap kualitas laba perusahaan, di mana dalam kondisi semakin besar utang, perusahaan cenderung melakukan praktik manajemen laba. Hal tersebut terjadi karena perusahaan tidak ingin mengambil risiko melanggar debt covenant yang berbiaya tinggi. Hasil penelitian juga melihat bahwa praktik manajemen laba di perusahaan berbasis syariah cenderung lebih rendah dibanding dengan perusahaan konvensional.

\section{Hipotesis}

Hipotesis yang dikembangkan untuk menjawab tujuan dari penelitian ini adalah sebagai berikut:

H0: Tidak ada perbedaan rata-rata kualitas laba di BUS dan UUS

H1: Terdapat perbedaan rata-rata kualitas laba di BUS dan UUS

H0: Kualitas laba BUS dan UUS tidak dipengaruhi oleh pembiayaan investasi bagi hasil

H1: Kualitas laba BUS dan UUS dipengaruhi oleh pembiayaan investasi bagi hasil

H0: Kualitas laba BUS dan UUS tidak dipengaruhi oleh utang (leverage)

H1: Kualitas laba BUS dan UUS dipengaruhi oleh utang (leverage) 


\section{METODE}

Data yang digunakan dalam penelitian ini adalah data sekunder, yakni laporan keuangan publikasi bank syariah berupa laporan posisi keuangan (neraca) dan laporan laba rugi untuk periode tahun 2008 sampai dengan 2017, yang diperoleh dari website Otoritas Jasa Keuangan (OJK). Teknik pengambilan sampel dilakukan secara sengaja (purposive sampling), dengan mengambil informasi keuangan yang terkait dengan perhitungan laba bank syariah, yaitu komponen arus kas operasional dan komponen akrual. Dalam penelitian ini, pengolahan data menggunakan aplikasi microsoft excel, sedangkan untuk menganalisis data menggunakan aplikasi statistika EViews.

Penelitian ini menggunakan metode kuantitatif sebagai berikut:

1) Untuk mengetahui kualitas akrual yang merupakan proksi dari kualitas laba Bank Umum Syariah (BUS) dan Unit Usaha Syariah (UUS), maka dilakukan regresi data panel dengan menggunakan persamaan model akrual dari Dechow-Dichev (2002) sebagai berikut:

$$
\Delta \mathrm{WC}_{\mathrm{j}, \mathrm{t}}=\alpha+\beta_{1} \mathrm{CFO}_{\mathrm{j}, \mathrm{t}-1}+\beta_{2} \mathrm{CFO}_{\mathrm{j}, \mathrm{t}}+\beta_{3} \mathrm{CFO}_{\mathrm{j}, \mathrm{t}+1}+\varepsilon_{\mathrm{j}, \mathrm{t}}
$$

Di mana:
$\Delta \mathrm{WC}_{\mathrm{j}, \mathrm{t}}$
: perubahan modal kerja (selisih aset dan liabilitas usaha) bank $\mathrm{j}$ pada periode $\mathrm{t}$
$\mathrm{CFO}_{\mathrm{j}, \mathrm{t}-1}$ : arus kas operasional bank $\mathrm{j}$ pada periode $\mathrm{t}-1$
$\mathrm{CFO}_{\mathrm{j}, \mathrm{t}}$
: arus kas operasional bank $\mathrm{j}$ pada periode $\mathrm{t}$
$\mathrm{CFO}_{\mathrm{j}, \mathrm{t}+1}$
: arus kas operasional bank $\mathrm{j}$ pada periode $\mathrm{t}+1$
$\varepsilon_{\mathrm{j}, \mathrm{t}}$
: nilai residual bank $\mathrm{j}$ pada periode $\mathrm{t}+1$

Kualitas akrual bank $\mathrm{j}$ pada periode $\mathrm{t}\left(\mathrm{AQ}_{\mathrm{j}, \mathrm{t}}\right)$ adalah merupakan standar deviasi dari nilai residual untuk tiga tahun terakhir $\left(\sigma\left(\varepsilon_{\mathrm{j}, \mathrm{t}}\right)\right.$, semakin kecil nilai stándar deviasi residualnya $\sigma\left(\varepsilon_{\mathrm{j}, \mathrm{t}}\right)$, maka semakin baik kualitas laba bank tersebut. Pelaksanaan pengujian model regresi data panel mengikuti prosedur umum termasuk uji pemilihan model common, fixed atau random effect (Gujarati dan Porter, 2009).

2) Untuk mengetahui Innate Accrual Quality (IAQ) dan Discretionary Accrual Quality (DAQ) yang merupakan proksi dari kualitas laba Bank Umum Syariah (BUS) dan Unit Usaha Syariah periode tahun 2014-2016, maka dilakukan regresi data panel dengan menggunakan persamaan model discretionary estimation error dari Francis et al. (2005) sebagai berikut:

$$
\mathrm{AQ}_{\mathrm{j}, \mathrm{t}}=\alpha+\lambda_{1} \mathrm{SIZE}_{\mathrm{j}, \mathrm{r}}+\lambda_{2} \sigma(\mathrm{CFO})_{\mathrm{j}, \mathrm{r}}+\lambda_{3} \sigma(\mathrm{SALES})_{\mathrm{j}, \mathrm{r}}+\lambda_{4} \log (\mathrm{OPCY})_{\mathrm{j}, \mathrm{r}}+\lambda_{5} \mathrm{NEG}_{\mathrm{j}, \mathrm{r}}+v_{\mathrm{j}, \mathrm{r}}
$$

Di mana:

$\mathrm{AQ}_{\mathrm{j}, \mathrm{t}} \quad$ : kualitas akrual bank $\mathrm{j}$ pada periode $\mathrm{t}$ (standar deviasi residual dari model akrual)

SIZE $_{\mathrm{j}, \mathrm{t}} \quad$ : logaritma natural dari total aset bank $\mathrm{j}$ pada periode $\mathrm{t}$

$\sigma(\mathrm{CFO})_{\mathrm{j}, \mathrm{r}} \quad$ : standar deviasi arus kas operasional tiga tahun terakhir bank $\mathrm{j}$ pada periode $\mathrm{t}$

$\sigma(\mathrm{SALES})_{\mathrm{j} r}$ : standar deviasi pendapatan operasional tiga tahun terakhir bank $\mathrm{j}$ pada periode $\mathrm{t}$

$\log (\mathrm{OPCY})_{\mathrm{j}, \mathrm{r}}$ : logaritma umur piutang bank $\mathrm{j}$ pada periode $\mathrm{t}$

$\mathrm{NEG}_{\mathrm{j}, \mathrm{r}} \quad$ : variabel dummy laba negatif (1: negatif, 0:positif) bank $\mathrm{j}$ pada periode $\mathrm{t}$

Innate Accrual Quality (IAQ $\mathrm{I}_{\mathrm{j}, \mathrm{t}}$ ) menujukkan kualitas laba yang berkaitan dengan karakteristik bank adalah rata-rata tiga tahun terakhir nilai estimasi $\mathrm{AQ}_{\mathrm{j}, \mathrm{t}}$ dari model kedua, di mana semakin besar nilainya maka semakin baik kualitas laba bank tersebut. Sedangkan Discretionary Accrual Quality $\left(\mathrm{DAQ}_{\mathrm{j}, \mathrm{t}}\right)$ adalah kualitas laba yang tidak berkaitan dengan karakteristik bank, diduga merupakan hasil dari praktik manajemen laba, ditunjukkan dengan nilai standar deviasi residual tiga tahun terakhir $\left(\sigma\left(v_{\mathrm{j}, \mathrm{r}}\right)\right)$, di mana semakin kecil nilai standar deviasi residualnya $\sigma\left(v_{\mathrm{j}, \mathrm{r}}\right)$ maka semakin baik kualitas laba bank tersebut. Pelaksanaan pengujian model regresi data panel mengikuti prosedur umum termasuk uji pemilihan model common, fixed atau random effect (Gujarati dan Porter, 2009).

3) Untuk mengidentifikasi perbedaan rata-rata kualitas laba di Bank Umum Syariah (BUS) dan Unit Usaha Syariah (UUS) periode tahun 2014-2016, maka dilakukan dengan metodo uji perbedaan dua 
sampel bebas (Independent Sample T-Test atau Mann-Whitney U-test). Pelaksanaan pengujian ratarata dua sampel bebas mengikuti prosedur umum termasuk pengujian asumsi normalitas dan homogenitas (Agung, 2006).

4) Untuk menganalisis pengaruh pembiayaan investasi bagi hasil (mudharabah dan musyarakah) dan utang (leverage) terhadap kualitas laba di Bank Umum Syariah (BUS) dan Unit Usaha Syariah periode tahun 2014-2016, maka digunakan metode regresi linear berganda cross-section dengan model persamaan sebagai berikut:

$$
\begin{aligned}
& \mathrm{IAQ}_{\mathrm{j}, \mathrm{t}}=\alpha+\beta_{1} \mathrm{MUD}_{\mathrm{j}, \mathrm{t}}+\beta_{2} \mathrm{LEV}_{\mathrm{j}, \mathrm{t}}+\varepsilon_{\mathrm{j}, \mathrm{t}} \\
& \mathrm{DAQ}_{\mathrm{j}, \mathrm{t}}=\alpha+\beta_{1} \mathrm{MUD}_{\mathrm{j}, \mathrm{t}}+\beta_{2} \mathrm{LEV}_{\mathrm{j}, \mathrm{t}}+\varepsilon_{\mathrm{j}, \mathrm{t}}
\end{aligned}
$$

Di mana:
$\mathrm{IAQ}_{\mathrm{j}, \mathrm{t}} \quad$ : Innate Accrual Quality (IAQ) bank j pada periode $\mathrm{t}$
DAQ $_{\mathrm{j}, \mathrm{t}} \quad$ : Discretionary Accrual Quality (DAQ) bank j pada periode $\mathrm{t}$
MUD $_{\mathrm{j}, \mathrm{t}} \quad$; pembiayaan investasi bagi hasil (mudharabah dan musyarakah) bank j pada periode $\mathrm{t}$
$\mathrm{LEV}_{\mathrm{j}, \mathrm{t}} \quad$ : utang (surat berharga dan pinjaman yang diterima) bank $\mathrm{j}$ pada periode $\mathrm{t}$

Pelaksanaan pengujian model regresi linear berganda (cross-section) mengikuti prosedur umum termasuk pengujian asumsi klasik (Winarno, 2007).

\section{HASIL DAN PEMBAHASAN}

\section{Deskripsi Statitistik}

Dari hasil pengumpulan informasi keuangan dari laporan publikasi neraca dan laba rugi bank syariah dalam kurun waktu tahun 2008 sampai dengan 2017, tidak seluruh data keuangan bank syariah dapat memenuhi data penelitian. Hanya data keuangan dari 8 Bank Umum Syariah (BUS) dan 17 Unit Usaha Syariah (UUS) yang dapat digunakan dalam penelitian ini.

Dalam kurun waktu tahun 2008 sampai dengan tahun 2017, sebagaimana ditunjukkan pada Tabel 1, rata-rata total aset BUS adalah sebesar Rp 16.57 triliun, sedangkan untuk UUS sebesar Rp 3.03 triliun. Selanjutnya rata-rata penyaluran pembiyaaan investasi bagi hasil dengan akad mudharabah dan musyarakah adalah masing-masing untuk BUS sebesar Rp 4.05 triliun dan UUS sebesar Rp 823.18 miliar. Untuk rata-rata utang dalam bentuk pinjaman dan penerbitan surat berharga, BUS ratarata memperoleh sebesar Rp 531.36 miliar dan UUS sebesar Rp 36.63 miliar. Sepanjang tahun 2008 sampai 2017, BUS menghasilkan rata-rata pendapatan operasional sebesar Rp 1.60 triliun dan laba bersih sebesar Rp 132.34 miliar. Sedangan UUS rata-rata memperoleh pendapatan operasional sebesar Rp 254.64 miliar dan laba bersih sebesar Rp 62.83 miliar.

Tabel 1 Rata-rata aset, investasi bagi hasil, utang, pendapatan, laba (dalam jutaan Rp)

\begin{tabular}{cccccc}
\hline Tipe & T-ASET & MUD & PINJ-SB & PEND-OPS & LABA-OPS \\
\hline BUS & $16,574,187$ & $4,055,753$ & 531,361 & $1,608,824$ & 132,346 \\
UUS & $3,039,213$ & 823,182 & 36,632 & 254,648 & 62,830 \\
\hline
\end{tabular}

Sumber: Laporan Keuangan Publikasi OJK, 2008-2017 (diolah)

Gambar 1 menggambarkan rata-rata distribusi pengelolaan dana dan kinerja bank syariah untuk periode tahun 2008 sampai dengan 2017. BUS mengelola rata-rata 85\% dari total aset bank syariah, $15 \%$ sisanya aset dikelola oleh UUS. Kemudian, penyaluran pembiayaan investasi bagi hasil (mudharabah dan musyarakah) rata-rata sebesar 83\% disalurkan oleh BUS, sedangkan UUS hanya menyalurkan pembiayaan sebesar $17 \%$. Dari seluruh total utang dalam bentuk pinjaman dan surat berharga, diterima oleh BUS sebesar 94\%, sedangkan UUS hanya menerima sebesar 6\%. Selanjutnya, BUS berkontribusi menghasilkan pendapatan operasional sebesar $86 \%$ dan laba bersih sebesar $68 \%$, sedangkan kontribusi UUS, untuk pendapatan opersional sebesar 14\% dan laba bersih sebesar $32 \%$. 


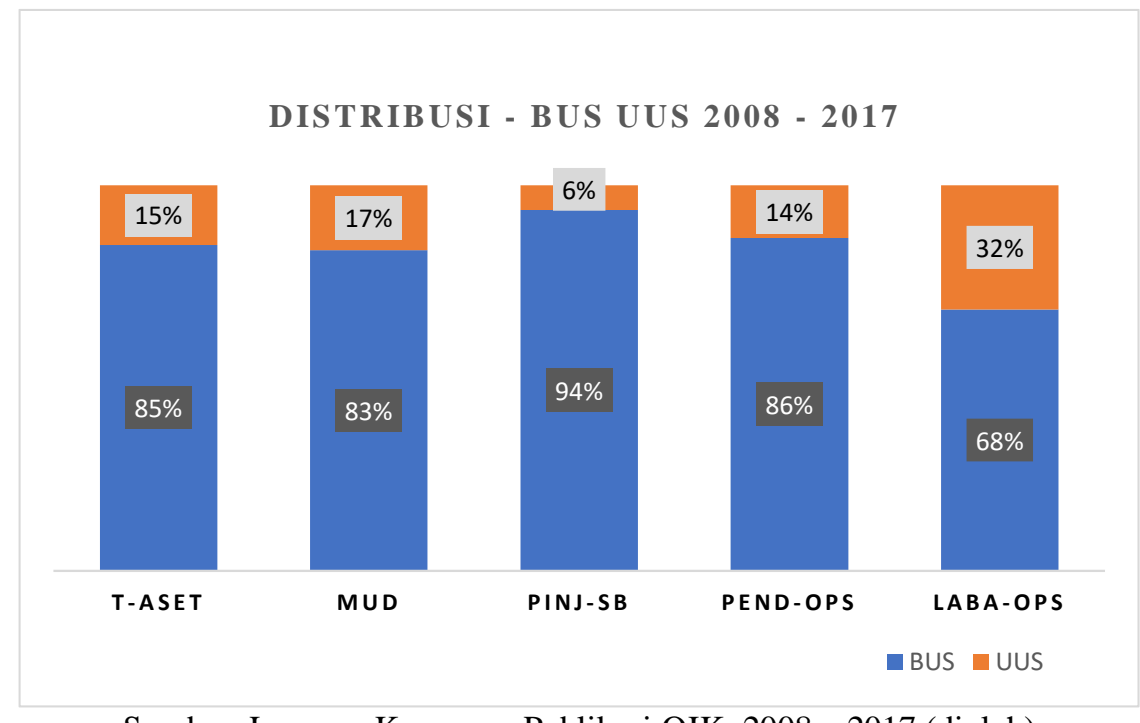

Sumber: Laporan Keuangan Publikasi OJK, 2008 - 2017 (diolah)

Gambar 1 Distribusi aset, pembiayaan hasil, utang, pendapatan, dan laba pada BUS dan UUS (\%)

\section{Kualitas Laba}

Makke (2016) mendefinisikan bahwa proksi kualitas laba yang pertama adalah kualitas akrual (AQ) yang dihitung dari standar deviasi nilai residual tiga tahun terakhir (2014-2016). Nilai residual diperoleh dari regresi modal kerja (WC) sebagai variabel terikat terhadap arus kas (CFO) periode masa lalu, saat ini dan yang akan datang sebagai variabel bebas.

Sementara proksi kualitas laba lainnya yakni Innate Accruals Quality (IAQ) yang merupakan nilai rata-rata estimasi kualitas akrual (AQ) tiga tahun terakhir (2014-2016) dan Discreationary Accruals Quality (DAQ) yang dihitung dari standar deviasi nilai residual tiga tahun terakhir (2014-2016). Kualitas laba IAQ dan DAQ diperoleh dari hasil regresi kualitas akrual (AQ) sebagai variabel terikat terhadap karakteristik perusahaan seperti ukuran perusahaan (SIZE), volatilitas arus kas (CFO) dan pendapatan (SALES), umur piutang (OPCY), serta historis laba negatif perusahaan (NEG) sebagai variabel bebas.

Tabel 2 Accruals Quality (AQ)

\begin{tabular}{lccc}
\hline Statistics & Full Sample & BUS & UUS \\
\hline Mean & 0.055398 & 0.050872 & 0.057529 \\
Median & 0.037820 & 0.046447 & 0.037813 \\
Standard Deviation & 0.190882 & 0.105351 & 0.190882 \\
Minimum & 0.004410 & 0.007609 & 0.004410 \\
Maximum & 0.051941 & 0.030271 & 0.060257 \\
Observation & 25 & 8 & 17 \\
\hline
\end{tabular}

Sumber: Laporan Keuangan Publikasi OJK, 2008-2017 (diolah)

Merujuk kepada Dechow \& Dichev (2002), perusahaan memiliki kualitas laba yang lebih baik apabila memiliki nilai standar deviasi residual yang lebih rendah. Hasil regresi data panel persamaan (1), ditunjukkan pada Tabel 2, di mana nilai rata-rata (mean) Accrual Quality (AQ) Bank Umum Syariah (BUS) adalah 0.050872 sedikit lebih rendah dibandingkan dengan rata-rata (mean) Unit Usaha Syariah (UUS) sebesar 0.057529, sehingga kualitas laba tipe BUS sedikit lebih baik dari tipe UUS. 
Tabel 3 Disrectionary Accruals Quality (DAQ)

\begin{tabular}{lccc}
\hline Statistics & Full Sample & BUS & UUS \\
\hline Mean & 0.026723 & 0.019355 & 0.030191 \\
Median & 0.021697 & 0.019541 & 0.021697 \\
Standard Deviation & 0.145456 & 0.035010 & 0.145456 \\
Minimum & 0.001258 & 0.007274 & 0.001258 \\
Maximum & 0.029071 & 0.008900 & 0.034542 \\
Observation & 25 & 8 & 17 \\
\hline
\end{tabular}

Sumber: Laporan Keuangan Publikasi OJK, 2008-2017 (diolah)

Sedangkan menurut Francis et al. (2005), perusahaan memiliki kualitas laba yang lebih baik apabila praktik manajemen laba di perusahaan tersebut rendah. Hasil regresi data panel persamaan (2), ditunjukkan pada Tabel 3, di mana BUS memiliki nilai rata-rata (mean) Discretionary Accruals Quality (DAQ) yakni 0.019355, lebih rendah dari nilai rata-rata (mean) yang dimiliki UUS yaitu sebesar 0.057529. Hal tersebut menyebabkan praktik manajemen laba di BUS cenderung lebih rendah. Hasil penelitian ini sejalan dengan dugaan awal karena pengelolaan BUS mengelola organisasinya lebih independen/tanpa intervensi dari perusahaan induk bank konvensional dibandingkan dengan UUS, sehingga kualitas laba BUS sedikit lebih baik dari UUS.

Sebagaimana ditunjukkan pada Tabel 2 dan Tabel 3, nilai minimum AQ adalah 0.004410 dan DAQ sebesar 0.001258 . Keduanya dimiliki oleh salah satu UUS, sehingga untuk sementara dapat dikatakan bahwa salah satu UUS memiliki kualitas laba yang paling baik dibandingkan dengan bank syariah lainnya, baik yang berasal dari kelompok BUS maupun UUS. Namun demikian, hal ini perlu diteliti lebih lanjut dengan pertimbangan bahwa dalam praktik operasional UUS terdapat keberadaan pencatatan akuntansi antara UUS dan bank konvensional sebagai perusahaan induknya yaitu penggunaaan Rekening Antar Kantor (RAK), di mana UUS berpotensi melalukan praktik manajemen laba melalui rekening ini. UUS dapat melakukan transfer biaya atau menerima dropping dana untuk menutupi kerugian yang terjadi di UUS, sehingga hal tersebut menjadi menjadi tanggungan bank konvensional induknya.

\section{Perbedaan Kualitas Laba}

Pengujian statistik dengan metode uji perbedaan dua sampel bebas dilakukan untuk mengidentifikasi apakah terdapat perbedaan signifikan rata-rata kualitas laba di Bank Umum Syariah (BUS) dan Unit Usaha Syariah (UUS). Untuk pengujian ini ditetapkan Innate Accrual Quality (IAQ) dan Discretionary Accrual Quality (DAQ) sebagai variabel terikat, sedangkan variabel bebasnya adalah tipe bank syariah yakni BUS dan UUS. Merujuk kepada penelitian Francis et al. (2005) dan Makke (2016), Innate Accruals Quality (IAQ) didefinisikan sebagai kualitas laba yang terkait dengan karakteristik perusahaan, sehingga penyajian laporan laba telah sesuai dengan transaksi yang mendasarinya. Sedangkan Discretionary Accruals Quality (DAQ) didefinisikan sebagai kualitas laba yang diduga sebagai terdapat rekayasa laba oleh perusahaan.

Hasil pengujian statistik untuk mengidentifikasi apakah terdapat perbedaan yang signifikan rata-rata kualitas laba Innate Accrual Quality (IAQ) antara BUS dan UUS tercantum pada Tabel 4, di mana nilai probabilitas dari uji Wilcoxon/Mann-Whitney adalah sebesar 0.7487. Nilai probabilitas tersebut lebih besar dari alpha $(\alpha)$ 0.05, maka hipotesis (H0) diterima. Sehingga dapat disimpulkan bahwa tidak ada perbedaan yang signifikan rata-rata kualitas laba Innate Accrual Quality (IAQ) untuk kedua tipe bank syariah BUS dan UUS. 
Tabel 4 Equality of median (IAQ)

\begin{tabular}{cccc}
\hline Bank Type & $\boldsymbol{N}$ & Mean Range & Median \\
\hline BUS & 8 & 12.2500 & 0.047968 \\
UUS & 17 & 13.5294 & 0.053775 \\
\hline Total & 25 & 13.0000 & 0.053775 \\
\hline Wilcoxon/Mann- & Prob \\
whitney & & 0.7487 & \\
\hline
\end{tabular}

Sumber: Laporan Keuangan Publikasi OJK, 2008-2017 (diolah)

Sedangkan hasil pengujian untuk mengidentikasi apakah terdapat perbedaan yang signifikan rata-rata kualitas laba Discretionary Accrual Quality (DAQ) antara BUS dan UUS tertera pada Tabel 5, di mana nilai probabilitas dari uji Wilcoxon/Mann-Whitney adalah 0.7487 . Nilai probabilitas tersebut lebih besar dari alpha $(\alpha)$ 0.05, maka hipotesis (H0) diterima. Sehingga dapat disimpulkan bahwa tidak ada perbedaan yang signifikan rata-rata kualitas laba Discretionary Accrual Quality (DAQ) untuk kedua tipe bank syariah BUS dan UUS.

Tabel 5 Equality of median (DAQ)

\begin{tabular}{cccc}
\hline Bank Type & $\boldsymbol{N}$ & Mean Range & Median \\
\hline BUS & 8 & 12.2500 & 0.019541 \\
UUS & 17 & 13.5294 & 0.021697 \\
\hline Total & 25 & 13.0000 & 0.021697 \\
\hline Wilcoxon/Mann- & & Prob & \\
whitney & & 0.7487 &
\end{tabular}

Sumber: Laporan Keuangan Publikasi OJK, 2008-2017 (diolah)

\section{Hubungan Pembiayaan, Utang dan Kualitas Laba}

Merujuk kepada Makke (2016), untuk menganalisis pengaruh pembiayaan investasi bagi hasil dengan akad mudharabah dan musyarakah serta dampak utang (leverage) terhadap kualitas laba, maka metode statistik yang digunakan adalah regresi linear berganda (cross-section). Kualitas laba dengan proksi Innate Earning Quality (IAQ) dan Discretionary Earning Quality (DAQ) sebagai variabel terikat. Sementara pembiayaan investasi bagi hasil (MUD) dan utang/leverage (LEV) sebagai variabel bebas.

Tabel 6 Regresi linear berganda - IAQ

\begin{tabular}{ccccc}
\hline $\begin{array}{c}\text { Dependent } \\
\text { Variable: } \text { IAQ }\end{array}$ & \multicolumn{2}{c}{ Type: BUS } & \multicolumn{2}{c}{ Type: UUS } \\
\hline Variable & \multirow{2}{*}{ Prob (t-statistic) } & $\begin{array}{l}\text { Prob (F- } \\
\text { statistic) }\end{array}$ & \multirow{2}{*}{ Prob (t-statistic) } & $\begin{array}{c}\text { Prob (F- } \\
\text { statistic) }\end{array}$ \\
\hline MUD & 0.1044 & 0.2063 & 0.3469 & 0.1909 \\
LEV & 0.4373 & & 0.2485 & \\
\hline
\end{tabular}

Sumber: Laporan Keuangan Publikasi OJK, 2008-2017 (diolah)

Hasil pengujian statistik atas persamaan (3) ditunjukkan pada Tabel 6, di mana kualitas laba IAQ BUS sebagai variabel terikat menunjukan nilai prob (t-statistic) untuk MUD sebesar 0.1044, LEV sebesar 0.4373 dan prob (F-statistic) sebesar 0.2063. Semua bernilai lebih besar dari alpha $(\alpha)=0.05$, maka hipotesis nol (H0) diterima. Hasil pengujian menyimpulkan bahwa baik secara individu maupun bersamaan, pembiayaan investasi bagi hasil (akad mudharabah dan musyarakah), serta utang (leverage) tidak memiliki pengaruh yang signifikan terhadap kualitas laba IAQ Bank Umum Syariah (BUS).

Selanjutnya masih pada Tabel 6, untuk kualitas laba IAQ - UUS sebagai variabel terikat, hasil pengujian menunjukan nilai prob (t-statistic) untuk MUD sebesar 0.3469, LEV sebesar 0.2485 dan prob (F-statistic) sebesar 0.1909. Semua memiliki nilai lebih besar dari alpha $(\alpha)=0.05$, sehingga hipotesis nol (H0) diterima. Sama seperti BUS, dapat disimpulkan bahwa pembiayaan investasi bagi 80 
hasil (akad mudharabah dan musyarakah) dan utang (leverage), baik secara individu dan bersamaan tidak memiliki pengaruh yang signifikan terhadap kualitas laba IAQ Unit Usaha Syariah (UUS).

Tabel 7 Regresi linear berganda - DAQ

\begin{tabular}{|c|c|c|c|c|}
\hline \multirow{2}{*}{$\begin{array}{c}\text { Dependent } \\
\text { Variable: IAQ } \\
\text { Variable }\end{array}$} & \multicolumn{2}{|c|}{ Type: BUS } & \multicolumn{2}{|c|}{ Type: UUS } \\
\hline & Prob (t-statistic) & $\begin{array}{l}\text { Prob (F- } \\
\text { statistic) }\end{array}$ & Prob (t-statistic) & $\begin{array}{l}\text { Prob (F- } \\
\text { statistic) }\end{array}$ \\
\hline MUD & 0.2699 & 0.6297 & 0.7568 & 0.8979 \\
\hline LEV & 0.3582 & & 0.5867 & \\
\hline
\end{tabular}

Sumber: Laporan Keuangan Publikasi OJK, 2008-2017 (diolah)

Pada Tabel 7, hasil pengujian regresi linear berganda (cross-section) untuk persamaan (4) dengan variabel terikat kualitas laba DAQ untuk tipe BUS, menunjukkan nilai prob (t-statistic) untuk MUD sebesar 0.2699, LEV sebesar 0.3582 dan prob (F-statistic) sebesar 0.6297. Untuk seluruh nilai tersebut lebih besar dari alpha $(\alpha)=0.05$, maka hipotesis nol $(\mathrm{H} 0)$ diterima. Sehingga dapat disimpulkan bahwa baik secara individu dan bersamaan, pembiayaan investasi bagi hasil (akad mudharabah dan musyarakah) dan utang (leverage) tidak memiliki pengaruh yang signifikan terhadap kualitas laba DAQ Bank Umum Syariah (BUS).

Sedangkan untuk variabel terikat DAQ untuk tipe UUS, sebagaimana yang ditunjukan pada Tabel 7, nilai prob (t-statistic) untuk MUD sebesar 0.7568, LEV sebesar 0.5867, dan prob (F-statistic) sebesar 0.8979 , dan semua nilai lebih besar dari alpha $(\alpha)=0.05$, maka hipotesis nol (H0) diterima. Sehingga dapat disimpulkan bahwa pembiayaan investasi bagi hasil (akad mudharabah dan musyarakah) dan utang (leverage) baik secara individu maupun bersamaan tidak signifikan mempengaruhi kualias laba DAQ Unit Usaha Syariah (UUS).

\section{SIMPULAN}

\section{Simpulan}

Pada periode pengamatan yakni saat terjadi pelemahan perekonomian Indonesia di tahun 2014 sampai dengan 2016 dapat disimpulkan sebagai berikut:

1. Dari pengujian untuk mengidentifkasi perbedaan dua sampel bebas terhadap kualitas laba di Bank Umum Syariah (BUS) dan Unit Usaha Syariah (UUS), disimpulkan bahwa tidak ada perbedaan yang signifikan rata-rata kualitas laba di kedua tipe tersebut baik untuk kualitas laba Innate Accrual Quality (IAQ) dan Discretionary Accrual Quality (DAQ).

2. Pembiayaan investasi bagi hasil (akad mudharabah dan musyarakah) dan utang (leverage) tidak memiliki pengaruh yang signifikan terhadap kualitas laba IAQ dan DAQ di Bank Umum Syariah (BUS) dan Unit Usaha Syaraih (UUS).

\section{Saran}

Berikut ini adalah saran-saran berdasarkan hasil penelitian:

1. Model akrual dapat digunakan sebagai salah pilihan alat untuk pengelolaan risiko baik di Bank Umum Syariah (BUS) maupun Unit Usaha Syariah (UUS).

2. Unit manajemen risiko (RMU) di bank konvensional diharapkan dapat menerapkan kebijakan dan perlakuan sama dalam pengelolaan risiko, khususnya terkait dengan risiko operasional di Unit Usaha Syariah (UUS), termasuk pemantauan terhadap kualitas laba yang tersaji di dalam laporan keuangan.

3. Penelitian selanjutnya dapat dilakukan dengan membandingkan kualitas laba bank syariah dengan bank konvensional. 


\section{DAFTAR PUSTAKA}

Agung, I G N. (2006). Statistika Penerapan Model Rerata Sel Multivariat dan Model Ekonometri. Jakarta (ID), Yayasan SAD Satria Bhakti.

Al Shattarat, W. K. \& Atmeh, M. A. (2016). Profit-sharing investment accounts in Islamic banks or mutualization, accounting perspective. Journal of Financial Reporting and Accounting, 14(1), $30-48$.

Banjarnahor, D. (2018). Revisi Laporan Keuangan, Laba Bukopin Telah Anjlok Sejak 2016 [Internet] [diakses 2019 Agu 31]. Tersedia pada: https://www.cnbcindonesia.com/market/2018042412190 4-17-12231/revisi-laporan-keuangan-laba-bukopin-telah-anjlok-sejak-2016.

Berndt, T. \& Offenhammer, C. (2010). Earnings management in the financial crisis 2007/2008: Evidence from German-Speaking Countries. In Proceeding of 2010 AAA Conference.

[BI] Bank Indonesia. (2013). Surat Edaran Bank Indonesia Nomor 15/26/DPbS Tanggal 10 Juli 2013 tentang Pedoman Akuntansi Perbankan Syariah Indonesia [Internet]. [diakses 2019 Agu 31]. Tersedia pada: https://www.bi.go.id/id/publikasi/peraturan/Pages/Surat\%20Edaran\%20Bank\% 20Indonesia\%20Nomor\%2015_26_DPbS\%20perihal\%20Pelaksanaan\%20Pedoman\%20Akunta nsi\%20Perbankan\%20Syariah.aspx.

[BI] Bank Indonesia. (2019). Nilai Tukar USD/IDR tahun 2011 - 2017 [Internet]. [diakses 2019 Agu 31]. Tersedia pada: https://www.bi.go.id/.

[BI] Bank Indonesia. (2019). Suku Bunga 2011 - 2017 [Internet]. [diakses 2019 Agu 31]. Tersedia pada: https://www.bi.go.id/.

[BPS] Badan Pusat Statistik. (2019). Pertumbuhan Perekonomian Nasional [Internet]. [diakses 2019 Agu 31]. Tersedia pada https://www.bps.go.id/publication/2017/09/27/96607b0fa1ba5649ce57 3500/laporan-perekonomian-indonesia-2017.html.

Chen Y, Chen C. H. \& Huang S. L. (2010). An appraisal of financially distressed companies' earning management: Evidence from listed companies in China. Pacific Accounting Review, 22(1), 2241.

DeAngelo, L. E. (1986). Accounting numbers as market valuation substitutes: A study of management buy-outs of public stockholders. The Accounting Review, 61(4), 400-420.

Dechow, P. M., Dichev, I. D. (2002). The quality of accruals and earnings: The role of accruals estimation errors. The Accounting Review, 77(1), 35-59.

Dechow, P. M., Ge, W., Schrand, C. (2010). Understanding earnings quality: a review of the proxies their determinants and their consequences. Journal of Accounting and Economics, 50(23), 344401.

Fauzia, M. (2019). Laporan Keuangan 2018 Direvisi, Garuda Indonesia Rugi Rp 2.45 Triliun [Internet]. [diakses 2019 Agu 31]. Tersedia pada https://money.kompas.com/read/2019/07/26/ 111246526/laporan-keuangan-2018-direvisi-garuda-indonesia-rugi-rp-245-triliun?page=all.

Francis, J., LaFond, R., Olsson, P. \& Schipper, K. (2005). The market pricing of accruals quality. Journal of Accounting and Economics, 39(2), 295-327.

Ghosh, A. \& Moon, D. (2010). Corporate debt financing and earnings quality. Journal of Business Finance and Accounting, 37(5), 538-559.

Gujarati, D. \& Porter, C. (2009). Basic Econometric. $5^{\text {th }}$ Edition. New York (US), McGraw-Hill Irwin.

Hamdi, F. M. \& Zarai, M A. (2012). Earnings management to avoid earnings decreases and losses: empirical evidence from Islamic banking industry. Research Journal Finance and Accounting, 3(3), 88-107.

Healy, P. M. (1985). The effect bonus schemes on accounting decisions. Journal of Accounting and Economics, 7(13), 85-107.

[IAI] Ikatan Akuntan Indonesia. (2017). Standar Akuntansi Keuangan Syariah. Jakarta (ID), IAI.

Jensen, M. C. \& Meckling, W. H. (1976). Theory of the firm: Managerial behaviour, agency costs and ownership structure. Journal of Financial Economics, 3(4): 305-360.

Johl, S. K., Jubb, C. A. \& Houghton, K. A. (2003, January). Audit quality: earnings management in the context of the Asian crisis. In Proceeding of 2003 AAA Conference. 
Jones, J. J. 1(991). Earnings management during import relief investigations. Journal of Accounting Research, 29(2), 193-228.

Kothari, S. P., Leone, A. J. \& Wasley, C. E. (2005). Performance matched discretionary accrual measures. Journal of Accounting and Economics, 39(1), 163-197.

Makke, R. (2016). Earnings Quality and Sharia Compliant Financial Firms during Recent Financial Cirisis: Degree of Compliance, Leverage and Country Effect. (Doctoral Dissertation, Alliant International University, Alhambra, United States).

[OJK] Otoritas Jasa Keuangan. (2019). Laporan Publikasi Bank Umum Syariah (BUS) dan Unit Usaha Syariah (UUS) [Internet]. [diakses 2019 Agu 31]. Tersedia pada: https://www.ojk.go.id/id/kanal/perbankan/data-dan-statistik/laporan-keuangan-perbankan/defau lt.aspx\#

[OJK] Otoritas Jasa Keuangan. (2019). Statistik Perbankan Syariah [Internet]. [diakses 2019 Agu 31]. Tersedia pada: https://www.ojk.go.id/id/kanal/syariah/data-dan-statistik/statistik-perbankansyariah/default.aspx.

Valipour, H. \& Moradbeygi, M. (2011). Corporate debt financing and earnings quality. Journal of Applied Finance and Banking, 1(3), 139-157.

Wan Abdullah, W. R. (2013). Earnings Management: Evidence Concerning Shariah-Approved Companies in Malaysia. (Doctoral Dissertation, Lincoln University, Lincoln, New Zealand).

Watt, R. L. \& Zimmerman, J. L. (1986). Positive Accounting Theory. $1^{\text {st }}$ Edition. New Jersey (US, Prince-Hall Inc.

Winarno, W. W. (2007). Analisis Ekonometrika dan Statistik dengan Eviews. Edisi ke-1. Yogyakarta (ID), UPP STIM YKPN Yogyakarta. 